\title{
The skeleton: a multi-functional complex organ. The growth plate chondrocyte and endochondral ossification
}

\author{
E J Mackie, L Tatarczuch and M Mirams \\ School of Veterinary Science, University of Melbourne, Parkville, Victoria 3010, Australia \\ (Correspondence should be addressed to E J Mackie; Email: ejmackie@unimelb.edu.au)
}

\begin{abstract}
Endochondral ossification is the process that results in both the replacement of the embryonic cartilaginous skeleton during organogenesis and the growth of long bones until adult height is achieved. Chondrocytes play a central role in this process, contributing to longitudinal growth through a combination of proliferation, extracellular matrix (ECM) secretion and hypertrophy. Terminally differentiated hypertrophic chondrocytes then die, allowing the invasion of a mixture of cells that collectively replace the cartilage tissue with bone tissue. The behaviour of growth plate chondrocytes is tightly regulated at all stages of endochondral ossification by a complex network of interactions between
\end{abstract}

circulating hormones (including GH and thyroid hormone), locally produced growth factors (including Indian hedgehog, WNTs, bone morphogenetic proteins and fibroblast growth factors) and the components of the ECM secreted by the chondrocytes (including collagens, proteoglycans, thrombospondins and matrilins). In turn, chondrocytes secrete factors that regulate the behaviour of the invading bone cells, including vascular endothelial growth factor and receptor activator of NFKB ligand. This review discusses how the growth plate chondrocyte contributes to endochondral ossification, with some emphasis on recent advances.

Journal of Endocrinology (2011) 211, 109-121

\section{Introduction}

Bones in different parts of the skeleton develop through two distinct processes, intramembranous ossification and endochondral ossification. Intramembranous ossification, which occurs in the flat bones of the skull, involves direct differentiation of embryonic mesenchymal cells into the bone-forming osteoblasts. In contrast, endochondral ossification, which occurs in the remainder of the skeleton, involves the replacement of a cartilage model by bone tissue.

The cartilage model of a prospective bone is formed as embryonic mesenchymal cells condense and differentiate into chondrocytes, which secrete the various components of cartilage extracellular matrix (ECM), including collagen type II and the proteoglycan aggrecan. The model expands through chondrocyte proliferation. Ossification of the cartilage model is preceded by hypertrophy of the chondrocytes in the prospective mid-shaft of the bone, and

\footnotetext{
This paper is one of three papers that form part of a thematic review section on the skeleton: a multi-functional complex organ. The Guest Editor for this section was Colin Farquharson, Roslin Institute, University of Edinburgh, UK.
}

deposition of a periosteal bone collar by recently differentiated osteoblasts surrounding the mid-shaft (Fig. 1). Blood vessels, osteoclasts (cartilage- and bone-resorbing cells), as well as bone marrow and osteoblast precursors then invade the model from the bone collar and proceed to form the primary centre of ossification. The primary centre expands towards the ends of the cartilage model, as the osteoclasts remove cartilage ECM and osteoblasts deposit bone on cartilage remnants. In long bones, a secondary ossification centre subsequently forms at each end of the cartilage model, leaving a cartilaginous growth plate between the primary and secondary ossification centres, as well as the prospective permanent articular cartilages at each end of the bone. The growth plate is responsible for longitudinal growth of bones. Skeletal maturity occurs when the expanding primary centre of ossification meets the secondary centre of ossification, thus obliterating the growth plate (Fig. 1).

Endochondral ossification is initiated during foetal life, and continues until growth ceases in early adulthood. Although endochondral ossification is dependent on the concerted actions of a number of cell types, it is the chondrocyte that drives the process. This review will focus on the role of the chondrocyte in endochondral ossification, with some emphasis on areas in which recent advances have been made. 


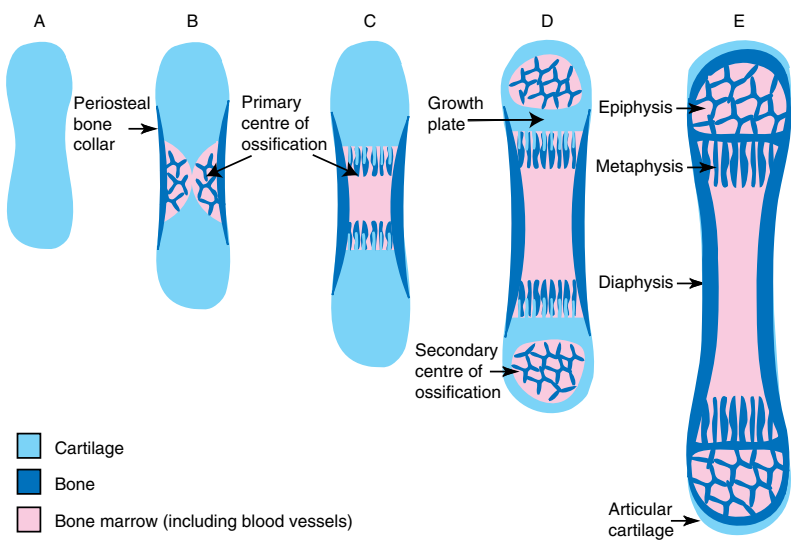

Figure 1 Overview of development of a bone by endochondral ossification. (A) The cartilage model of the future bone.

(B) A periosteal bone collar has formed and formation of the primary centre of ossification has been initiated. (C) The primary centre of ossification is starting to expand towards the ends of the cartilage model. (D) The secondary centres of ossification have formed at each end of the bone, leaving a cartilaginous growth plate between primary and secondary centres of ossification. (E) Skeletal maturity has been achieved, with complete replacement of the growth plate cartilage by bone. The only cartilage remaining is the articular cartilage at the ends of the bone.

\section{The growth plate chondrocyte models its own environment}

At all stages of endochondral ossification, from the initiation of formation of the primary centre to the final stages of adolescent growth, the chondrocytes contributing to this process participate in an orderly sequence of events that are reflected in their morphology; the different stages of the chondrocyte lifespan are visible in distinct zones in sections through the growth plate (Fig. 2). First, chondrocytes undergo proliferation, which is observed as the presence of pairs of chondrocytes in a single lacuna within the cartilage ECM, before their separation from each other by secretion of ECM (Figs 2 and 3). Following proliferation, the chondrocytes undergo a period of high secretory activity, as they deposit the typical cartilage ECM components around themselves, while remaining in multicellular clusters, often arranged in columns parallel to the long axis of the bone. These cells gradually undergo hypertrophy, modelling their surrounding ECM as they expand, and then mineralising it. Following hypertrophy, chondrocytes undergo physiological death, and the transverse septa of the cartilage ECM surrounding them are removed, allowing entry of the mixture of cells responsible for the expansion of the ossification centre. Thus, the growth plate chondrocyte plays multiple important roles during its lifespan. It constructs the transient growth plate tissue, which has the necessary capacity to move in space through continued self-renewal and localised degradation, but simultaneously maintains the mechanical stability of the growing bone. Accumulating evidence indicates that the growth plate chondrocyte orchestrates the invasion of its own domain by the ossification front not only through preparation of the cartilage tissue, but also by secreting soluble molecules that regulate the behaviour of the invading cells.

\section{Contribution to bone elongation}

The growth plate chondrocyte contributes to bone elongation through a combination of proliferation, ECM secretion and hypertrophy. The relative contributions of these parameters vary with growth rate, which varies with anatomical location, age and species; the higher the growth rate the greater the contribution from cellular hypertrophy and the smaller the contribution from matrix synthesis (Wilsman et al. 1996). These functions of the chondrocyte are tightly controlled by circulating molecules such as hormones, as well as by substances produced locally by the chondrocytes themselves (summarised in Fig. 4). Mutations in the genes encoding these regulatory molecules result in abnormal chondrocyte behaviour and skeletal dysplasias, most of which are associated with dwarfism, i.e. inadequate growth of the bones that form by endochondral ossification (Krakow \& Rimoin 2010).

\section{Proliferation}

An important stimulator of chondrocyte proliferation in the growth plate is $\mathrm{GH}$, which is produced in the pituitary gland. $\mathrm{GH}$ exerts its effects on the growth plate predominantly

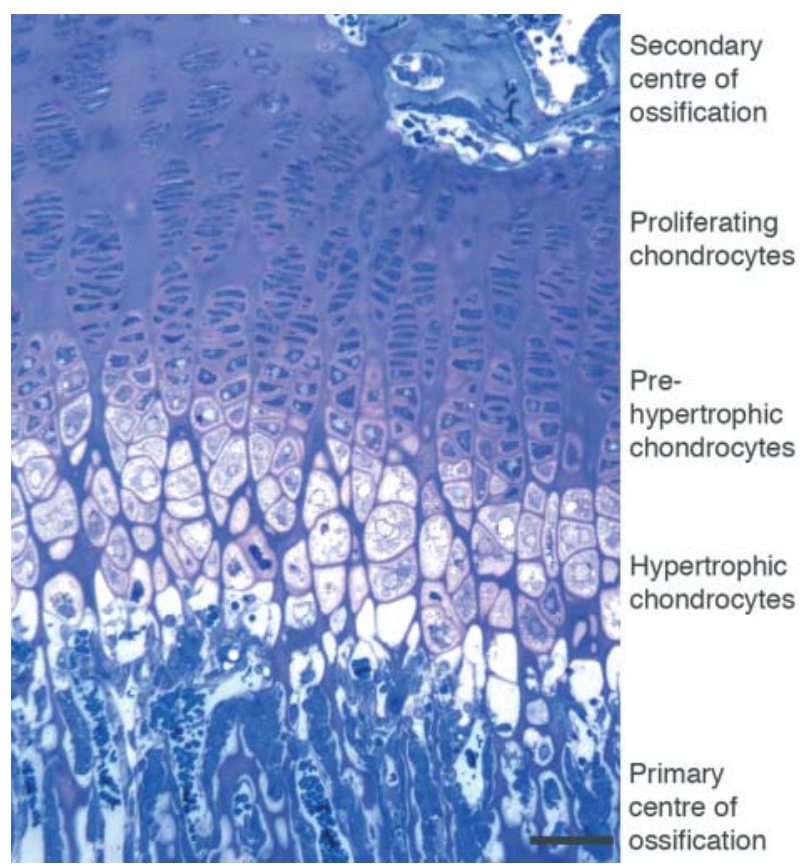

Figure 2 Growth plate morphology. Section through the proximal growth plate of the tibia from a 3-week-old mouse; the section is oriented longitudinally with respect to the bone; bar $=50 \mu \mathrm{m}$. 

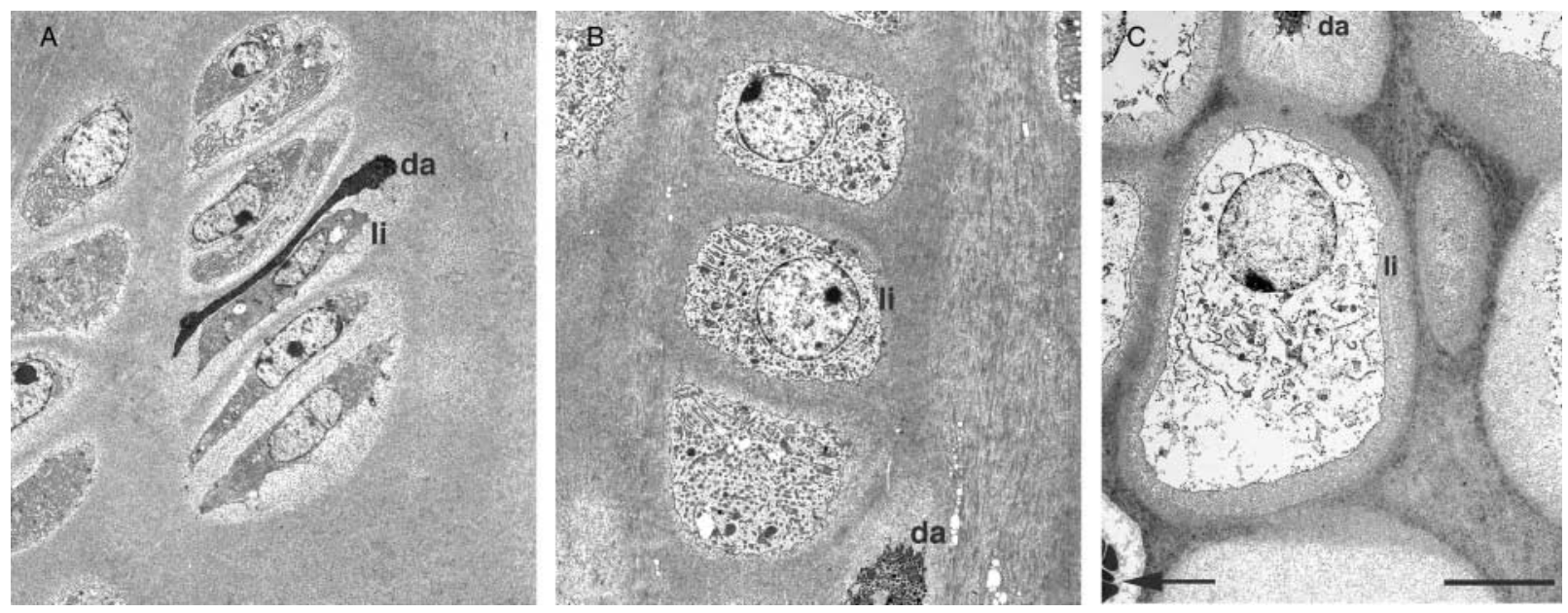

Figure 3 The changing morphology of growth plate chondrocytes. Chondrocytes in a section through the proximal growth plate of a 4-weekold rat tibia, examined by transmission electron microscopy. (A) Zone of proliferative chondrocytes, where pairs of cells that have recently undergone proliferation have not yet separated from each other. (B) Zone of early hypertrophic chondrocytes, where ECM now separates the cells. (C) Zone of late hypertrophic chondrocytes, including the last lacunae before the ossification front, which can be identified by the presence of erythrocytes (arrow). The majority of cells are light (li) chondrocytes, but occasional dark (da) chondrocytes are visible in all zones. All figure parts are the same magnification; bar $=10 \mu \mathrm{m}$.

through stimulation of secretion of insulin-like growth factor 1 (IGF1), both by liver cells and by growth plate chondrocytes (Nilsson et al. 2005, Pass et al. 2009). The importance of the GH/IGF1 axis is underlined by the excessive growth observed in children with elevated GH levels due to pituitary tumours, and the inadequate growth observed in children with GH deficiency or mutations in the genes encoding components of the GH response pathway. It is likely that suppression of activity of the GH/IGF1 axis by inflammatory cytokines is partly responsible for the growth defects observed in children with chronic inflammatory conditions, who generally show reduced levels of IGF1 (Pass et al. 2009). A second IGF, IGF2, is expressed in the growth plate independently of $\mathrm{GH}$, and is required for normal embryonic growth (DeChiara et al. 1991). All of IGF1's effects and most of IGF2's effects are mediated by the type I IGF receptor, and mice lacking this receptor demonstrate a more severe growth defect than mice lacking either of the IGFs (Baker et al. 1993).

Indian hedgehog (IHH) is secreted by chondrocytes undergoing the transition from proliferation to hypertrophy, known as 'prehypertrophic' chondrocytes; IHH is required for normal chondrocyte proliferation during both embryonic and postnatal growth (Koyama et al. 1996, St-Jacques et al. 1999, Maeda et al. 2007). Substantial differences in Ihh expression levels are associated with inter-breed differences in growth rate in dogs (Tryfonidou et al. 2010). IHH exerts its effects by binding to its cell surface receptor patched 1 (Ptch1), which normally suppresses signalling through the membrane protein smoothened (Smo), but binding of $\mathrm{Hh}$ to Ptch1 reverses inhibition of Smo and allows IHH pathway signalling to occur. Responses of chondrocytes to IHH are mediated by members of the Gli family of transcriptional regulators (Wuelling \& Vortkamp 2010). In the presence of
IHH signalling, these proteins promote transcription of $\mathrm{IHH}$ target genes, but when IHH is absent, Gli2 and Gli3 are subject to proteolytic conversion into transcriptional repressors. IHH stimulates chondrocyte proliferation through inactivation of the repressor form of Gli3, in particular, as demonstrated by the phenotype of double IHH-null/Gli3null mice (Ehlen et al. 2006). IHH binds to aggrecan through its chondroitin sulphate side chains, and in the mouse growth plate normal sulphation of chondroitin sulphate is required for normal IHH protein distribution and signalling, and for chondrocyte proliferation (Cortes et al. 2009). IHH signalling, and thus proliferation of growth plate chondrocytes, is also dependent on the presence of an intact primary cilium, a structure consisting of a basal body and a ciliary axoneme that extends several micrometres from the surface of the chondrocyte and most other cells (Wilsman et al. 1980, Poole et al. 1985, Koyama et al. 2007).

WNTs are a family of secreted proteins that play multiple roles in skeletal development and maintenance (Yates et al. 2005). Binding of WNTs to their receptor Frizzled (Frz) in combination with the co-receptor Lrp5 or Lrp6 leads to activation of the canonical WNT signalling pathway which involves accumulation of $\beta$-catenin, whereas binding to Frz alone leads to activation of the non-canonical (calciumdependent kinase $\mathrm{C}$-mediated) pathway which can result in degradation of $\beta$-catenin. A number of WNTs are expressed by growth plate chondrocytes and are capable of stimulating their proliferation, but there is disagreement in the literature as to whether $\beta$-catenin mediates this effect (Yang et al. 2003, Akiyama et al. 2004, Mak et al. 2006, Andrade et al. 2007, Chen et al. 2008).

The bone morphogenetic proteins (BMPs) are members of the transforming growth factor $\beta$ (TGF $\beta$ ) superfamily. 
Hormones Factors secreted by chondrocytes

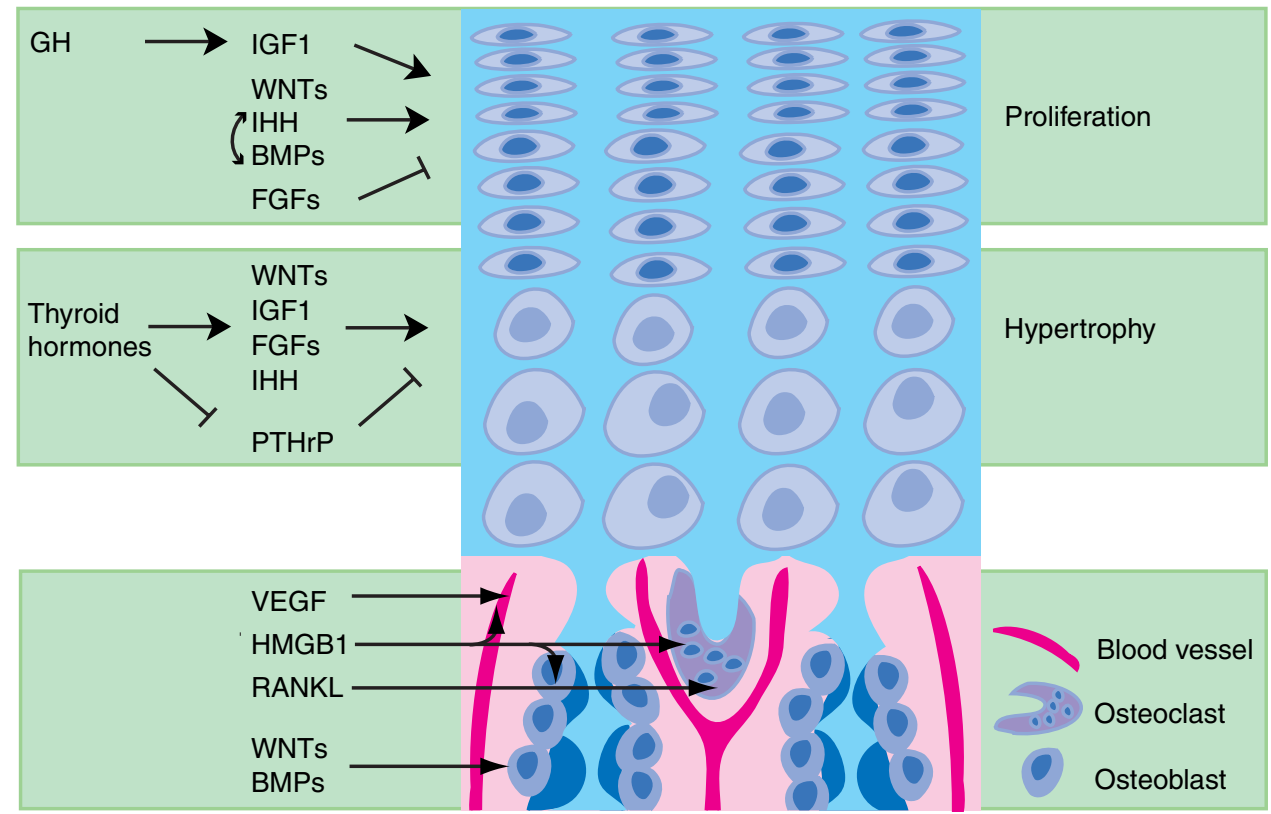

Figure 4 Overview of the effects of factors secreted by chondrocytes on growth plate cell function and invasion. Under the control of circulating hormones, chondrocytes secrete growth factors that act on chondrocytes to regulate their proliferation and hypertrophy (upper two panels), and on cells of the ossification front (lower panel), to regulate their invasion of the growth plate cartilage. Arrows indicate stimulatory pathways, and crossed lines indicate inhibitory pathways. Not all effects mentioned in the text are included in this figure.

Activation of BMP signalling in the growth plate results in chondrocyte proliferation (Minina et al. 2001, Yoon et al. 2006). BMP receptors are complexes of type I and type II serine/ threonine kinase receptors, which when activated phosphorylate receptor-Smads, causing their translocation to the nucleus. The receptor-Smads responsible for BMP signalling in chondrocytes are Smads 1 and 5, which appear to have overlapping functions (Retting et al. 2009). Phosphorylation of Smads 1 and 5 in chondrocytes is dependent on the presence of neogenin, which is a receptor for the neuronal axon guidance cues netrins and repulsive guidance molecules (Zhou et al. 2010). Neogenin's role in this process appears to be to mediate the association of the BMP receptor with membrane microdomains (lipid rafts). Schnurri proteins are large zinc finger adapter proteins that can bind to and cooperate with Smads in induction of BMP-responsive genes (Jin et al. 2006). A recent study has demonstrated that mice that lack both $S h n 2$ and Shn3 (but not each gene individually) show defects in endochondral ossification including inadequate chondrocyte proliferation, an effect that is likely to be due to failure of BMP signalling (Jones et al. 2010). BMPs induce IHH expression and $\mathrm{IHH}$ induces expression of various BMPs in growth cartilage, but neither of these factors is absolutely dependent on expression of the other for its effects on chondrocyte proliferation (Grimsrud et al. 2001, Minina et al. 2001).

Fibroblast growth factors (FGFs) acting through FGF receptor 3 (FGFR3) are important regulators of chondrocyte proliferation, but activation of this receptor represses proliferation rather than promoting it (Ornitz 2005). Achondroplasia, the most common form of short-limbed dwarfism in humans, as well as some other human skeletal dysplasias, result from activating mutations in FGFR3 (Ornitz 2005, Krakow \& Rimoin 2010). A number of FGFs are capable of activating FGFR3, and on the basis of expression and gene manipulation studies in mice, it has been concluded that the most important activator in the growth plate is likely to be FGF18 (Ornitz 2005). In the human growth plate, however, the predominantly expressed FGFs are FGFs 1, 2, 15 and 19 (Krejci et al. 2007). FGFR3 is a tyrosine kinase receptor, and its suppression of chondrocyte proliferation in the growth plate appears to be mediated by STAT1 (Ornitz 2005). The activity of FGFs, like that of IHH, is modulated by glycosaminoglycans. Mice that lack sulphatase-modifying factor 1, which activates sulphatases (and thus proteoglycan desulphation) show dwarfism, which can be rescued by crossing with FGF18-null mice (Settembre et al. 2008). Thus, it appears that FGF-induced repression of chondrocyte proliferation is limited by the desulphation of glycosaminoglycans. The relevant glycosaminoglycan is most likely to be heparan sulphate, found in proteoglycans such as perlecan in the cartilage ECM (Bishop et al. 2007, Rodgers et al. 2008, Chuang et al. 2010). BMP signalling antagonises the inhibition of chondrocyte proliferation caused by activation of FGFR3 (Minina et al. 2002). 
Chondrocyte proliferation in response to growth factors including IHH is mediated by cyclins which form complexes with cyclin-dependent kinases, ultimately leading to activation of E2F transcription factors and cell cycle progression (Wuelling \& Vortkamp 2010). Cyclin D1, in particular, is required for normal proliferation of growth plate chondrocytes, as demonstrated by studies in cyclin D1-null mice (Beier et al. 2001). The ability of chondrocytes to express normal levels of cyclin D1, and thus undergo normal proliferation, is dependent on the presence of the transcriptional repressor TRPS1. This protein derives its name from tricho-rhino-phalangeal syndrome, a condition in humans involving skeletal malformations, which results from mutations in the TRPS1 gene. TRPS1-null mice demonstrate abnormally low levels of proliferation in growth plate chondrocytes, which can be attributed to a role for TRPS1 in repression of STAT3 expression, which in turn allows for elevated expression of cyclin D1 (Suemoto et al. 2007). It is interesting to note that TRPS1 binds the transcriptional activator form of Gli3, but the implications of this binding for chondrocyte proliferation in the growth plate are as yet unclear (Wuelling et al. 2009, Wuelling \& Vortkamp 2010).

Conversely, inhibition of chondrocyte proliferation in response to activation of FGFR 3 is accompanied by induction of inhibitors of cyclin-dependent kinase including p21, presumably thereby causing cell cycle arrest (Dailey et al. 2003). Further information about the mechanism by which FGFR 3 causes early cell cycle exit is provided by the results of expression array studies comparing chondrocytes isolated from human foetuses affected by thanatophoric dysplasia caused by activating FGFR 3 mutations with chondrocytes isolated from normal foetuses; among other observations concerning cell cycle-related genes, the FGFR 3 mutations are associated with lower levels of cell cycle-related E2F target genes (Schibler et al. 2009).

\section{Extracellular matrix}

Secretion of ECM by growth plate chondrocytes makes an important contribution to growth. Cartilage ECM consists primarily of large aggregates of aggrecan and the glycosaminoglycan hyaluronan, packed in amongst fibrils of collagen type II (Gentili \& Cancedda 2009, Heinegard 2009). These three components of cartilage ECM confer on the growth plate the mechanical stability required by this integral component of the growing skeleton. The collagen fibrils provide the framework for the tissue and the strongly hydrophilic hyaluronan-aggrecan aggregates allow the tissue to withstand compression. Both collagen type II and aggrecan are almost exclusively expressed in cartilage.

Cartilage ECM also contains a number of less abundant collagens, proteoglycans and other non-collagenous proteins, which, together with the three major cartilage constituents, form a complex network of interacting molecules (Gentili \& Cancedda 2009, Heinegard 2009). The relative abundance of many of the cartilage ECM constituents varies between zones of the growth plate. Minor cartilage collagens include collagen types VI, IX, X, XI, XII and XIV. Cartilage proteoglycans, in addition to aggrecan, include the small leucine-rich proteoglycans decorin, biglycan and fibromodulin, as well as the large proteoglycan perlecan. Other non-collagenous proteins found in cartilage ECM include the matrilins and thrombospondin family members, such as thrombospondin-5, also known as cartilage oligomeric matrix protein (COMP). Many of the less abundant molecules make important contributions to cartilage ECM assembly and, together with the major cartilage constituents, influence the behaviour of chondrocytes (Heinegard 2009, Klatt et al. 2011).

The importance of the complex interactions between cartilage ECM components for growth is illustrated by the effects of mutations in humans or mice in the genes encoding a number of the proteins. For some of these molecules, the complete absence of the protein has no detrimental effect, but mutations causing a failure of secretion from the endoplasmic reticulum (ER) result in retention of the mutant protein and its binding partners in the ER as well as growth defects (Zaucke \& Grässel 2009, Klatt et al. 2011). Pseudoachondroplasia in humans is caused by mutations in COMP, and the milder multiple epiphyseal dysplasia can be caused by mutations in the genes encoding COMP, collagen type IX or matrilin-3 (Briggs \& Chapman 2002). Many of the COMP mutations result in misfolding of COMP, and the chondrocytes from these patients retain not only COMP but also collagen type IX and matrilin-3 in their ER, and the ECM is depleted of all these proteins (Hecht et al. 2005). Secretion of aggrecan and collagen type II is not affected by the mutations, but the collagen does not form organised fibril bundles, indicating that the $\mathrm{COMP} /$ collagen IX/matrilin-3 complexes are required for normal cartilage matrix organisation and growth plate structure. Mice lacking COMP or matrilin-3 show no abnormality in skeletal development or growth, and mice lacking collagen type IX exhibit a mild growth defect, suggesting that these proteins are at least partly able to substitute for each other (Fässler et al. 1994, Hagg et al. 1997, Svensson et al. 2002, Ko et al. 2004). Generation of mice lacking both COMP and collagen type IX did not show any greater disturbance of the growth plate than did mice lacking collagen type IX alone, but the ECM of these growth plates still contains some matrilin-3, so perhaps the additional deletion of matrilin-3 and/or possibly other proteins is required for the demonstration of functional redundancy (Blumbach et al. 2008, Posey et al. 2008). It is interesting to note that in these mice the additional deletion of the COMPrelated protein thrombospondin-3, which alone causes no obvious growth plate defect, caused a significantly greater disruption of growth plate organisation and limb length reduction (Posey et al. 2008).

In addition to the protein components of cartilage ECM, hyaluronan plays an important role in the contribution of ECM secretion to growth. Mice in which the gene for hyaluronan synthase 2 (Has 2 ) is inactivated in tissues derived from limb bud 
mesoderm possess abnormally short limbs (Matsumoto et al. 2009). The growth plates from these mice contain abnormally low levels of hyaluronan; they show a decrease in the deposition of aggrecan and a decrease in the amount of matrix separating the chondrocytes, manifest as an increase in cell density in the absence of any effect on proliferation.

Expression and secretion of components of cartilage ECM, including collagen type II and aggrecan are stimulated by a variety of soluble factors present in the growth plate, including IGF1, BMPs and other members of the TGF $\beta$ superfamily, and are absolutely dependent on the transcription factor SOX9 (Bi et al. 1999, Lefebvre \& Smits 2005, Tew et al. 2008). SOX9activated transcription appears to be modulated by epigenetic mechanisms, since it occurs predominantly in hyperacetylated chromatin; the histone acetyltransferase p300 associates with SOX9 and enhances SOX9-dependent transcription. Moreover, inhibition of histone deacetylases (HDACs) stimulates expression of SOX9-activated cartilage ECM genes and induces histone acetylation in the region of the Col2a1 enhancer in primary chondrocyte cultures (Furumatsu et al. 2005). Overexpression of HDAC1 or 2 in chondrocytes results in down-regulation of expression of Aggrecan and Col2a1, providing further evidence for epigenetic control of this aspect of chondrocyte function (Hong et al. 2009).

\section{Hypertrophy}

As post-proliferative chondrocytes undergo hypertrophy, they experience changes in gene expression that allow them to modify the structure and composition of the surrounding ECM. The synthesis of collagen type II is down regulated and the synthesis of the non-fibrillar collagen type $\mathrm{X}$, expression of which is specific to hypertrophic chondrocytes, is initiated (van der Eerden et al. 2003). Hypertrophic chondrocytes also selectively express matrix metalloproteinase 13 (MMP13), a collagenase capable of degrading fibrils of collagen type II Johansson et al. 1997, Cawston \& Young 2010). Post-proliferative growth plate chondrocytes exist as two populations, which are described as light and dark cells on the basis of their appearance when viewed by transmission electron microscopy (Fig. 3; Anderson 1964, Hwang 1978, Wilsman et al. 1981, Roach \& Clarke 2000, Ahmed et al. 2007). The fact that these two populations could only be identified by electron microscopy has made it difficult to study their functional differences, but the recent identification of periostin as a dark chondrocyte-associated protein will assist in research in this area (Chen et al. 2010).

It may seem logical to assume that chondrocytes would need to degrade the ECM immediately surrounding themselves to undergo the enormous increase in volume described as hypertrophy (Fig. 3), however, none of the enzymes known to both degrade the components of cartilage ECM and be expressed by hypertrophic chondrocytes are required for the process of hypertrophy. The chondrocytes of MMP13-null mice undergo apparently normal hypertrophy, indicating that collagen degradation is not necessary (Inada et al. 2004, Stickens et al. 2004). Similarly, aggrecan degradation does not appear to be required. There are no morphological defects in the growth cartilage of mice in which aggrecan is rendered resistant to MMP cleavage (Little et al. 2005a). A disintegrin and metalloproteinase with thrombospondin motifs (ADAMTS) family of enzymes includes ADAMTS-1, -4 and -5 , which are capable of cleaving aggrecan; mice lacking each of these individually (Little et al. 2005b, Stanton et al. 2005) or ADAMTS-4 and -5 in combination (Rogerson et al. 2008) show normal growth plate morphology. The results of the latter study indicate that an additional, as yet unidentified, aggrecan-degrading activity is present in mouse cartilage, thus a role for aggrecan cleavage in chondrocyte hypertrophy cannot yet be ruled out. It seems likely, however, that ECM degradation is not in fact required for chondrocytes to expand in volume. Observations on the role of hyaluronan in the growth plate may provide some insight into this problem of how the chondrocyte is able to expand so dramatically. Results of studies in which growth plate organ cultures were treated with hyaluronidase have provided evidence for a role for hyaluronan in the enlargement of the lacunae of hypertrophic chondrocytes (Pavasant et al. 1996). Moreover, in the Has2-null mice mentioned-above, as well as having reduced matrix volume, the growth plates show an almost complete failure of chondrocyte hypertrophy, based on both morphology and expression of hypertrophy-associated genes (Matsumoto et al. 2009). As noted by these authors, the role of hyaluronan may be to initiate hypertrophy-inducing intracellular signalling in chondrocytes emerging from the proliferative phase. Given the importance of hyaluronan-aggrecan complexes for swelling of the growth plate ECM, however, it is likely that this swelling per se is required for the concomitant expansion of the chondrocyte. Recently proliferated chondrocytes are flattened in the longitudinal axis of the growing bone, and the subsequent increase in cell volume is manifest as a disproportionate increase in height, relative to width of the cell, that is, in the direction of bone growth (Fig. 3; Breur et al. 1994). Perhaps the role of hyaluronan is to provide sufficient space between collagen fibrils to ensure that the chondrocyte can displace the surrounding matrix as it expands.

Just as proliferation of the growth plate chondrocyte is regulated, both positively and negatively, by systemic and locally produced extracellular molecules, so is the transition from the proliferative to the hypertrophic state. Thyroid hormones are important systemic regulators of chondrocyte hypertrophy (Shao et al. 2006). In vitro, the thyroid hormone triiodothyronine $\left(\mathrm{T}_{3}\right)$ stimulates morphological hypertrophy as well as molecular markers of hypertrophy, without stimulating proliferation (Burch \& Lebovitz 1982, Bohme et al. 1992, Ballock \& Reddi 1994, Wang et al. 2007). Hypothyroidism in humans results in slowing of longitudinal bone growth, with abnormally thin growth plates and impaired chondrocyte hypertrophy. Studies in genetically manipulated mice have demonstrated that the receptor 
responsible for these effects is thyroid hormone receptor $\alpha$ (and not thyroid hormone receptor $\beta$; Kaneshige et al. 2001).

The mediators of thyroid hormone-induced chondrocyte hypertrophy are starting to be identified, but the mechanism of this response has not yet been fully elucidated. One such pathway appears to be WNT/ $\beta$-catenin signalling. WNTs not only stimulate chondrocyte proliferation as noted above, but also promote chondrocyte hypertrophy (EnomotoIwamoto et al. 2002, Dong et al. 2006). A number of studies in genetically manipulated mice with either constitutive activation or depletion of components of the $\beta$-catenin signalling pathway have demonstrated that activation of this pathway promotes chondrocyte hypertrophy; thus, it appears most likely that the effect of WNTs on chondrocyte hypertrophy is mediated by the canonical WNT signalling pathway (Tamamura et al. 2005, Chen et al. 2008, Kawasaki et al. 2008). In chondrocytes in vitro, $\mathrm{T}_{3}$ up-regulates Wnt4 mRNA and protein expression as well as cellular accumulation of $\beta$-catenin, and inhibition of WNT signalling by secreted WNT antagonists inhibits $\mathrm{T}_{3}$-induced hypertrophy, providing strong evidence that WNT signalling contributes to thyroid hormone-induced hypertrophy (Wang et al. 2007). In addition, these effects of $T_{3}$ are partially inhibited by inhibitors of IGF1 signalling, indicating that IGF1 also makes some contribution to thyroid hormone-induced hypertrophy (Wang et al. 2010). $T_{3}$ also induces expression of FGFR 3 in chondrocyte-like cells and the growth plates of thyroid hormone receptor $\alpha$-null mice express substantially lower levels of FGFR 3 than do those of wild-type animals (Barnard et al. 2005). Since activation of FGFR 3 results in acceleration of hypertrophy, this receptor appears to be another mediator of thyroid hormone-induced chondrocyte hypertrophy (Minina et al. 2002, Ornitz 2005).

The IHH secreted by prehypertrophic chondrocytes is another factor that not only influences proliferation, but also hypertrophy, which it is generally considered to inhibit (Vortkamp et al. 1996, Maeda et al. 2007). This effect of IHH is mediated by Gli2, and Gli2-dependent stimulation of secretion of parathyroid hormone-related peptide (PTHrP; Vortkamp et al. 1996, Kronenberg 2006, Joeng \& Long 2009). $\mathrm{PTHrP}$ suppresses hypertrophy, thus keeping the cells in a proliferative state (Lee et al. 1996). PTHrP exerts this effect at least in part through inhibition of expression of the transcription factor RUNX2; RUNX2 induces chondrocytic transcription of hypertrophy-associated genes including col10a1 and promotes hypertrophy (Lefebvre \& Smits 2005, Guo et al. 2006). The suppression of hypertrophy by PTHrP is probably also mediated by SOX9, which is activated by PTHrP through protein kinase A-dependent phosphorylation and indirectly inhibits RUNX2 expression (Huang et al. 2000, 2001, Akiyama et al. 2002, Yamashita et al. 2009). PTHrP stimulates cyclin D1 expression in chondrocytes, and is unable to down-regulate RUNX2 expression in chondrocytes from cyclin D1-null mice, apparently because cyclin D1 contributes to proteasomal degradation of RUNX2 (Beier et al. 2001, Zhang et al. 2009). The transcriptional co-regulator Zfp521, which is induced by PTHrP, has also recently been identified as an effector of PTHrP's actions in the growth plate; the growth cartilage of mice with chondrocyte-specific deletion of Zfp521 resembles that of PTHrP-null mice, and PTHrP is unable to stimulate cyclin D1 expression or inhibit RUNX2 expression in the absence of Zfp521 (Correa et al. 2010).

Expression of PTHrP by growth plate chondrocytes is inhibited by TRPS1, as demonstrated by studies in TRPS1null mice and accompanying in vitro studies (Nishioka et al. 2008). Mice with a heterozygous in-frame deletion of the DNA-binding domain of TRPS1 show elevated expression of RUNX2 in the growth plate; moreover, TRPS1 directly interacts with RUNX2 to inhibit its function (Napierala et al. 2008). These observations suggest that TRPS1 acts to finetune cell cycle exit and progression to the hypertrophic state, by limiting both the antihypertrophic activity of PTH and the pro-hypertrophic activity of RUNX2, while at the same time supporting proliferation in a cyclin D1-dependent manner (mentioned above in the section on proliferation; Suemoto et al. 2007).

In vivo studies in rats indicate that thyroid hormones suppress expression of both $\mathrm{PTHrP}$ and its receptor, thus providing another potential mechanism by which thyroid hormones induce chondrocyte hypertrophy (Stevens et al. 2000). It has recently been demonstrated that in the absence of PTHrP, IHH promotes chondrocyte hypertrophy, an effect that is likely to be mediated by WNT and BMP signalling pathways (Mak et al. 2008). Furthermore, complex interactions between the locally secreted factors that regulate chondrocyte behaviour in the growth plate include the fact that FGFs antagonise BMP-induced IHH expression, an effect that is relevant to the FGFs' effect on hypertrophy, but not proliferation (Minina et al. 2002, Retting et al. 2009).

\section{Degradation and invasion of growth plate cartilage}

\section{Mineralisation}

Hydroxyapatite crystals (composed primarily of calcium and phosphate) are deposited in the ECM surrounding late hypertrophic chondrocytes. The matrix vesicles released by these cells contain a combination of proteins including phosphate transporters, phosphatases and annexins and provide the nucleation site for mineralisation (Anderson 1969, Kirsch et al. 1997, Kirsch 2006). In vitro studies identified annexins 5 and 6 as calcium channels with a potential role in calcium deposition in matrix vesicles, however, the results of a recent study in mice lacking both of these proteins have ruled out an essential role for them in mineralisation of growth plate cartilage (Kirsch et al. 2000, Genge et al. 2007a,b, Belluoccio et al. 2010). It may be that other members of the annexin family expressed by hypertrophic chondrocytes compensate for the loss of these two proteins. The phosphatases PHOSPHO1 and tissue 
non-specific alkaline phosphatase, both contribute to mineralisation of cartilage ECM. Recent studies involving individual and combined ablation of the genes encoding these phosphatases in mice suggest that PHOSPHO1 plays a role in the initiation of matrix vesicle mineralisation, while alkaline phosphatase activity is required for normal progression of mineralisation beyond the confines of the matrix vesicle (Fedde et al. 1999, Anderson et al. 2004, Yadav et al. 2011). The role of alkaline phosphatase activity in mineralisation in the growth plate is thought to be to remove extracellular pyrophosphate, which is a putative inhibitor of mineralisation (Kirsch 2006). Carminerin, a transcriptional inhibitor of nucleotide pyrophosphatase/phosphodiesterase 1, is also required for normal mineralisation of growth plate ECM; carminerin-null mice show no abnormality in growth plate morphology other than reduced mineralisation (Yamada et al. 2006). This observation suggests that growth plate mineralisation is not required for normal function of the growth plate itself. The importance of growth plate mineralisation may lie in provision of an appropriate composition for the remnants of cartilage matrix on which bone is deposited in the primary centre of ossification, since bone volume in the newly formed bone of the metaphysis is reduced in the absence of carminerin (Yamada et al. 2006).

\section{Chondrocyte death}

Most hypertrophic chondrocytes appear to undergo rapid death in the last row of lacunae before the ossification front. A number of publications have described these cells as dying by apoptosis, but the evidence for this conclusion is based on the detection of molecular features known to be associated with apoptosis, such as DNA strand breaks and caspase activation, rather than on the more definitive morphological changes observed on ultrastructural examination (Gibson 1998, Adams \& Shapiro 2002, Correa et al. 2010). Cells undergoing apoptosis show intense condensation of chromatin into geometric shapes, and fragmentation of the nucleus and cytoplasm into membrane-bound apoptotic bodies (Kerr et al. 1972). A number of careful ultrastructural studies have failed to identify chondrocytes undergoing apoptosis in growth plates of several species (Roach \& Clarke 1999, Colnot et al. 2001, Roach et al. 2004, Emons et al. 2009). In fact, light and dark hypertrophic chondrocytes appear to die by cell type-specific (non-apoptotic) mechanisms (Ahmed et al. 2007). Each of these cell types undergoes a distinctive series of morphological changes following hypertrophy: light chondrocytes appear to disintegrate within their cell membrane and dark chondrocytes progressively extrude their cytoplasm into the extracellular space. Nuclear condensation occurs very late and is irregular.

\section{Matrix degradation}

Degradation of the cartilage matrix surrounding growth plate chondrocytes does not appear to be required for hypertrophy, as noted in the section on chondrocyte hypertrophy above, but it is required for invasion of the growth plate by the cells of the centre of ossification. In the lacunae closest to the ossification front, the transverse septa separating the chondrocytes from the invading cells are broken down, leaving many of the vertical septa intact to provide a scaffold for deposition of bone matrix (Fig. 2). Both the collagenase MMP13, expressed by hypertrophic chondrocytes, and MMP9, which cleaves denatured collagens and aggrecan and is expressed by cells within the ossification front, are required for normal growth plate cartilage removal ( $\mathrm{Vu}$ et al. 1998, Inada et al. 2004, Stickens et al. 2004). It appears that the removal of collagen rather than of aggrecan is the limiting factor in this process, given the lack of an abnormal growth plate phenotype in mice with MMP-resistant aggrecan and mice lacking the aggrecan-degrading ADAMTSs (Little et al. 2005a,b, Stanton et al. 2005, Rogerson et al. 2008).

Osteoclasts at the ossification front are also required for normal growth plate cartilage matrix degradation, as demonstrated in mice treated with pharmacological inhibitors of osteoclast activity (bisphosphonates) and in osteopetrotic mouse mutants, which lack osteoclasts (Deckers et al. 2002). In the absence of osteoclastic activity, the growth plate is elongated because, with the exception of blood vessels, the cells of the ossification centre are unable to invade it (Deckers et al. 2002). Osteoclastic resorption of bone is primarily dependent on the lysosomal cysteine proteinase cathepsin $\mathrm{K}$, but growth plate cartilage degradation is not dramatically altered by failure to express cathepsin K (Saftig et al. 1998). Since osteoclasts express MMP9, and there is abnormal retention of growth plate cartilage in MMP9-null mice, it appears that osteoclasts depend more on this enzyme than on cathepsin K for their degradation of cartilage matrix (Reponen et al. 1994, Vu et al. 1998).

Osteoclasts are not, however, the first cells to invade the growth plate. It has been noted that blood vessels appear to precede osteoclasts as the first cells that enter the lacunae recently vacated by dying hypertrophic chondrocytes, thus it is not particularly surprising that they are able to invade the growth plate in the absence of osteoclast activity (Schenk et al. 1967, Deckers et al. 2002). Another cell type that has recently been described as accompanying the blood vessels at the ossification front is the 'septoclast', a perivascular cell that expresses cathepsin B; it has been proposed that septoclasts assist in the degradation of the transverse cartilage septa, thus allowing entry of capillaries (Lee et al. 1995, Gartland et al. 2009).

\section{Regulation of behaviour of invading cells}

In addition to osteoclasts, septoclasts and capillaries and their contents, the invading cells of the primary ossification centre include osteoblasts and bone marrow cells. The osteoblasts deposit bone matrix on the remaining vertical septa of cartilage, resulting in the formation of the trabecular (spongy) bone of the metaphysis. A number of recent studies have 
provided evidence that growth plate chondrocytes produce factors that regulate the behaviour of these invading cells (summarised in Fig. 4), thus presumably ensuring that the rate of replacement of cartilage by bone is matched to the preparation of the growth plate for invasion.

As chondrocytes undergo hypertrophy, under the control of RUNX2 they increase their expression of vascular endothelial growth factor, which promotes the vascular invasion of the growth plate (Zelzer et al. 2001, 2004). High-mobility group box 1 protein (HMGB1) is secreted by hypertrophic chondrocytes, and acts as a chemoattractant for endothelial cells, osteoclasts and osteoblasts; HMGB1-null mice display delayed invasion of the growth plate by cells of the ossification centre (Taniguchi et al. 2007). Another factor expressed by hypertrophic chondrocytes that promotes invasion by osteoclasts is receptor activator of NFKB ligand (RANKL), which is essential for osteoclast differentiation (Kishimoto et al. 2006). Hypertrophic chondrocytes stimulate osteoclast differentiation in vitro in a RANKL-dependent manner, and RANKL expression by cultured chondrocytes is stimulated by BMP2 and mediated by RUNX2 (Usui et al. 2008). A possible role for WNTs released by chondrocytes in increasing osteoblast numbers has been suggested by the finding that levels of $\beta$-catenin protein and markers of osteoblast differentiation are abnormally low in the primary spongiosa of mice with a postnatally induced chondrocytespecific knockout of $I H H$ (Maeda et al. 2007). Furthermore, evidence for regulation of osteoblast behaviour by growth plate chondrocytes has been provided by studies in mice expressing an activating Fgfr 3 mutant under the control of the Col2a1 (chondrocyte-specific) or Col1a1 (osteoblast-specific) promoter (Matsushita et al. 2009). Activation of FGFR3 signalling in chondrocytes, but not osteoblasts, caused an increase in osteoblast numbers at the chondro-osseous junction, an effect that is likely to be mediated by the stimulation of BMP ligand expression and inhibition of BMP antagonist expression observed in these mice (Matsushita et al. 2009).

Collectively, these observations indicate that chondrocytes of the growth plate release soluble factors that allow them to delicately control the behaviour of the invading vascular endothelial cells, osteoclasts and osteoblasts, which all have important roles in transforming growth plate cartilage into bone tissue.

\section{Growth plate closure}

As skeletal maturity approaches, the rate of advancement of the ossification front is greater than the rate at which growth plate chondrocytes replace themselves. The growth plate cartilage disappears as the primary centre of ossification meets the secondary centre and bony fusion occurs (Fig. 1). In human males as well as females, oestrogen regulates this process, as demonstrated by the failure of normal growth plate closure in patients with oestrogen deficiency or oestrogen resistance (Smith et al. 1994, Morishima et al. 1995). It is thought that growth plate closure occurs when the chondrocytes exhaust their proliferative potential, and that the role of oestrogen is to accelerate this process of senescence (Weise et al. 2001). Oestrogen receptors expressed by growth plate chondrocytes are likely to mediate these effects (Nilsson et al. 2005).

\section{Conclusion}

As demonstrated in this review, the understanding of the role of the growth plate chondrocyte in endochondral ossification has increased enormously in recent years, largely as a result of the identification of gene mutations responsible for human chondrodysplasias, and discoveries making use of recent advances in gene manipulation technologies for in vitro and in vivo studies, supported by careful morphological characterisation. There is still much to learn about this process. The molecular bases of some chondrodysplasias remain undiscovered, and for many of those for which the responsible genes have been identified, the links between mutation and disease are incompletely elucidated. Although chondrocytes, the major structural components of the matrix they produce and components of the major signalling pathways that regulate their behaviour have been extensively studied, there are still many gaps in our knowledge. The process by which a single cell type, the chondrocyte, provides the impetus for the growth of rigid bones from embryonic life to adulthood is a fascinating area of study, which will no doubt keep us occupied for many years to come.

\section{Declaration of interest}

The authors declare that there is no conflict of interest that could be perceived as prejudicing the impartiality of the review reported.

\section{Funding}

This review did not receive any specific grant from any funding agency in the public, commercial or not-for-profit sector.

\section{References}

Adams CS \& Shapiro IM 2002 The fate of the terminally differentiated chondrocyte: evidence for microenvironmental regulation of chondrocyte apoptosis. Critical Reviews in Oral Biology and Medicine 13 465-473. (doi:10. 1177/154411130201300604)

Ahmed YA, Tatarczuch L, Pagel CN, Davies HM, Mirams M \& Mackie EJ 2007 Physiological death of hypertrophic chondrocytes. Osteoarthritis and Cartilage 15 575-586. (doi:10.1016/j.joca.2006.10.016)

Akiyama H, Chaboissier MC, Martin JF, Schedl A \& de Crombrugghe B 2002 The transcription factor Sox 9 has essential roles in successive steps of the chondrocyte differentiation pathway and is required for expression of Sox 5 and Sox6. Genes and Development 16 2813-2828. (doi:10.1101/gad. 1017802)

Akiyama H, Lyons JP, Mori-Akiyama Y, Yang X, Zhang R, Zhang Z, Deng JM, Taketo MM, Nakamura T, Behringer RR et al. 2004 Interactions between Sox 9 and beta-catenin control chondrocyte differentiation. Genes and Development 18 1072-1087. (doi:10.1101/gad.1171104) 
Anderson DR 1964 The ultrastructure of elastic and hyaline cartilage of the rat. American Journal of Anatomy 114 403-434. (doi:10.1002/aja. 1001140305)

Anderson HC 1969 Vesicles associated with calcification in the matrix of epiphyseal cartilage. Journal of Cell Biology 41 59-72. (doi:10.1083/jcb.41.1.59)

Anderson HC, Sipe JB, Hessle L, Dhanyamraju R, Atti E, Camacho NP \& Millan JL 2004 Impaired calcification around matrix vesicles of growth plate and bone in alkaline phosphatase-deficient mice. American Journal of Pathology 164 841-847. (doi:10.1016/S0002-9440(10)63172-0)

Andrade AC, Nilsson O, Barnes KM \& Baron J 2007 Wnt gene expression in the post-natal growth plate: regulation with chondrocyte differentiation. Bone 40 1361-1369. (doi:10.1016/j.bone.2007.01.005)

Baker J, Liu JP, Robertson EJ \& Efstratiadis A 1993 Role of insulin-like growth factors in embryonic and postnatal growth. Cell 75 73-82. (doi:10.1016/S0092-8674(05)80085-6)

Ballock RT \& Reddi AH 1994 Thyroxine is the serum factor that regulates morphogenesis of columnar cartilage from isolated chondrocytes in chemically defined medium. Journal of Cell Biology 126 1311-1318. (doi:10.1083/jcb.126.5.1311)

Barnard JC, Williams AJ, Rabier B, Chassande O, Samarut J, Cheng SY, Bassett JH \& Williams GR 2005 Thyroid hormones regulate fibroblast growth factor receptor signaling during chondrogenesis. Endocrinology 146 5568-5580. (doi:10.1210/en.2005-0762)

Beier F, Ali Z, Mok D, Taylor AC, Leask T, Albanese C, Pestell RG \& LuValle P 2001 TGFbeta and PTHrP control chondrocyte proliferation by activating cyclin D1 expression. Molecular Biology of the Cell 12 3852-3863.

Belluoccio D, Grskovic I, Niehoff A, Schlotzer-Schrehardt U, Rosenbaum S, Etich J, Frie C, Pausch F, Moss SE, Poschl E et al. 2010 Deficiency of annexins $\mathrm{A} 5$ and $\mathrm{A} 6$ induces complex changes in the transcriptome of growth plate cartilage but does not inhibit the induction of mineralization. Journal of Bone and Mineral Research 25 141-153. (doi:10.1359/jbmr.090710)

Bi W, Deng JM, Zhang Z, Behringer RR \& de Crombrugghe B 1999 Sox9 is required for cartilage formation. Nature Genetics 22 85-89. (doi:10.1038/ 8792)

Bishop JR, Schuksz M \& Esko JD 2007 Heparan sulphate proteoglycans fine-tune mammalian physiology. Nature 446 1030-1037. (doi:10.1038/ nature05817)

Blumbach K, Niehoff A, Paulsson M \& Zaucke F 2008 Ablation of collagen IX and COMP disrupts epiphyseal cartilage architecture. Matrix Biology 27 306-318. (doi:10.1016/j.matbio.2007.11.007)

Bohme K, Conscience-Egli M, Tschan T, Winterhalter KH \& Bruckner P 1992 Induction of proliferation or hypertrophy of chondrocytes in serumfree culture: the role of insulin-like growth factor-I, insulin, or thyroxine. Journal of Cell Biology 116 1035-1042. (doi:10.1083/jcb.116.4.1035)

Breur GJ, Turgai J, Vanenkevort BA, Farnum CE \& Wilsman NJ 1994 Stereological and serial section analysis of chondrocytic enlargement in the proximal tibial growth plate of the rat. Anatomical Record 239 255-268. (doi:10.1002/ar.1092390304)

Briggs MD \& Chapman KL 2002 Pseudoachondroplasia and multiple epiphyseal dysplasia: mutation review, molecular interactions, and genotype to phenotype correlations. Human Mutation 19 465-478. (doi:10.1002/ humu.10066)

Burch WM \& Lebovitz HE 1982 Triiodothyronine stimulates maturation of porcine growth-plate cartilage in vitro. Journal of Clinical Investigation 70 496-504. (doi:10.1172/JCI110641)

Cawston TE \& Young DA 2010 Proteinases involved in matrix turnover during cartilage and bone breakdown. Cell Tissue Research 339 221-235. (doi:10.1007/s00441-009-0887-6)

Chen M, Zhu M, Awad H, Li TF, Sheu TJ, Boyce BF, Chen D \& O’Keefe RJ 2008 Inhibition of beta-catenin signaling causes defects in postnatal cartilage development. Journal of Cell Science 121 1455-1465. (doi:10.1242/ jcs.020362)

Chen KS, Tatarczuch L, Mirams M, Ahmed YA, Pagel CN \& Mackie EJ 2010 Periostin expression distinguishes between light and dark hypertrophic chondrocytes. International Journal of Biochemistry and Cell Biology 42 880889. (doi:10.1016/j.biocel.2010.01.018)
Chuang CY, Lord MS, Melrose J, Rees MD, Knox SM, Freeman C, Iozzo RV \& Whitelock JM 2010 Heparan sulfate-dependent signaling of fibroblast growth factor 18 by chondrocyte-derived perlecan. Biochemistry $\mathbf{4 9}$ 5524-5532. (doi:10.1021/bi1005199)

Colnot C, Sidhu SS, Balmain N \& Poirier F 2001 Uncoupling of chondrocyte death and vascular invasion in mouse galectin 3 null mutant bones. Developmental Biology 229 203-214. (doi:10.1006/dbio.2000.9933)

Correa D, Hesse E, Seriwatanachai D, Kiviranta R, Saito H, Yamana K, Neff L, Atfi A, Coillard L, Sitara D et al. 2010 Zfp521 is a target gene and key effector of parathyroid hormone-related peptide signaling in growth plate chondrocytes. Developmental Cell 19533-546. (doi:10.1016/j.devcel.2010.09.008)

Cortes M, Baria AT \& Schwartz NB 2009 Sulfation of chondroitin sulfate proteoglycans is necessary for proper Indian hedgehog signaling in the developing growth plate. Development 136 1697-1706. (doi:10.1242/dev. 030742)

Dailey L, Laplantine E, Priore R \& Basilico C 2003 A network of transcriptional and signaling events is activated by FGF to induce chondrocyte growth arrest and differentiation. Journal of Cell Biology 161 1053-1066. (doi:10.1083/jcb.200302075)

DeChiara TM, Robertson EJ \& Efstratiadis A 1991 Parental imprinting of the mouse insulin-like growth factor II gene. Cell 64 849-859. (doi:10.1016/ 0092-8674(91)90513-X)

Deckers MM, Van Beek ER, Van Der Pluijm G, Wetterwald A, Van Der WeePals L, Cecchini MG, Papapoulos SE \& Lowik CW 2002 Dissociation of angiogenesis and osteoclastogenesis during endochondral bone formation in neonatal mice. Journal of Bone and Mineral Research 17 998-1007. (doi:10. 1359/jbmr.2002.17.6.998)

Dong YF, Soung do Y, Schwarz EM, O'Keefe RJ \& Drissi H 2006 Wnt induction of chondrocyte hypertrophy through the Runx2 transcription factor. Journal of Cell Physiology 208 77-86. (doi:10.1002/jcp.20656)

van der Eerden BC, Karperien M \& Wit JM 2003 Systemic and local regulation of the growth plate. Endocrine Reviews 24 782-801. (doi:10. 1210/er.2002-0033)

Ehlen HW, Buelens LA \& Vortkamp A 2006 Hedgehog signaling in skeletal development. Birth Defects Research. Part C, Embryo Today: Reviews $\mathbf{7 8}$ 267-279. (doi:10.1002/bdrc.20076)

Emons J, Chagin AS, Hultenby K, Zhivotovsky B, Wit JM, Karperien M \& Savendahl L 2009 Epiphyseal fusion in the human growth plate does not involve classical apoptosis. Pediatric Research 66 654-659. (doi:10.1203/ PDR.0b013e3181beaa8c)

Enomoto-Iwamoto M, Kitagaki J, Koyama E, Tamamura Y, Wu C, Kanatani N, Koike T, Okada H, Komori T, Yoneda Tet al. 2002 The Wnt antagonist Frzb-1 regulates chondrocyte maturation and long bone development during limb skeletogenesis. Developmental Biology 251 142-156. (doi:10. 1006/dbio.2002.0802)

Fässler R, Schnegelsberg PN, Dausman J, Shinya T, Muragaki Y, McCarthy MT, Olsen BR \& Jaenisch R 1994 Mice lacking alpha 1 (IX) collagen develop noninflammatory degenerative joint disease. PNAS 91 5070-5074. (doi:10.1073/pnas.91.11.5070)

Fedde KN, Blair L, Silverstein J, Coburn SP, Ryan LM, Weinstein RS, Waymire K, Narisawa S, Millan JL, MacGregor GR et al. 1999 Alkaline phosphatase knock-out mice recapitulate the metabolic and skeletal defects of infantile hypophosphatasia. Journal of Bone and Mineral Research 14 2015-2026. (doi:10.1359/jbmr.1999.14.12.2015)

Furumatsu T, Tsuda M, Yoshida K, Taniguchi N, Ito T, Hashimoto M \& Asahara H 2005 Sox 9 and p300 cooperatively regulate chromatin-mediated transcription. Journal of Biological Chemistry 280 35203-35208. (doi:10. 1074/jbc.M502409200)

Gartland A, Mason-Savas A, Yang M, MacKay CA, Birnbaum MJ \& Odgren PR 2009 Septoclast deficiency accompanies postnatal growth plate chondrodysplasia in the toothless (tl) osteopetrotic, colony-stimulating factor-1 (CSF-1)-deficient rat and is partially responsive to CSF-1 injections. American Journal of Pathology 175 2668-2675. (doi:10.2353/ ajpath.2009.090185)

Genge BR, Wu LN \& Wuthier RE 2007a In vitro modeling of matrix vesicle nucleation: synergistic stimulation of mineral formation by annexin A5 and phosphatidylserine. Journal of Biological Chemistry 282 26035-26045. (doi:10.1074/jbc.M701057200) 
Genge BR, Wu LN \& Wuthier RE $2007 b$ Kinetic analysis of mineral formation during in vitro modeling of matrix vesicle mineralization: effect of annexin A5, phosphatidylserine, and type II collagen. Analytical Biochemistry 367 159-166. (doi:10.1016/j.ab.2007.04.029)

Gentili C \& Cancedda R 2009 Cartilage and bone extracellular matrix. Current Pharmaceutical Design 15 1334-1348. (doi:10.2174/13816120 9787846739)

Gibson G 1998 Active role of chondrocyte apoptosis in endochondral ossification. Microscopic Research and Technique 43 191-204. (doi:10.1002/ (SICI)1097-0029(19981015)43:2 < 191::AID-JEMT10>3.0.CO;2-T)

Grimsrud CD, Romano PR, D’Souza M, Puzas JE, Schwarz EM, Reynolds PR, Roiser RN \& O’Keefe RJ 2001 BMP signaling stimulates chondrocyte maturation and the expression of Indian hedgehog. Journal of Orthopaedic Research 19 18-25. (doi:10.1016/S0736-0266(00)00017-6)

Guo J, Chung UI, Yang D, Karsenty G, Bringhurst FR \& Kronenberg HM 2006 PTH/PTHrP receptor delays chondrocyte hypertrophy via both Runx2-dependent and -independent pathways. Developmental Biology 292 116-128. (doi:10.1016/j.ydbio.2005.12.044)

Hagg R, Hedbom E, Mollers U, Aszodi A, Fässler R \& Bruckner P 1997 Absence of the alpha1(IX) chain leads to a functional knock-out of the entire collagen IX protein in mice. Journal of Biological Chemistry 272 20650-20654. (doi:10.1074/jbc.272.33.20650)

Hecht JT, Hayes E, Haynes R \& Cole WG 2005 COMP mutations, chondrocyte function and cartilage matrix. Matrix Biology 23 525-533. (doi:10.1016/j.matbio.2004.09.006)

Heinegard D 2009 Proteoglycans and more - from molecules to biology. International Journal of Experimental Pathology 90 575-586. (doi:10.1111/j. 1365-2613.2009.00695.x)

Hong S, Derfoul A, Pereira-Mouries L \& Hall DJ 2009 A novel domain in histone deacetylase 1 and 2 mediates repression of cartilage-specific genes in human chondrocytes. FASEB Journal 23 3539-3552. (doi:10.1096/fj.09133215)

Huang W, Zhou X, Lefebvre V \& de Crombrugghe B 2000 Phosphorylation of SOX9 by cyclic AMP-dependent protein kinase A enhances SOX9's ability to transactivate a Col2a1 chondrocyte-specific enhancer. Molecular and Cellular Biology 20 4149-4158. (doi:10.1128/MCB.20.11.4149-4158. 2000)

Huang W, Chung UI, Kronenberg HM \& de Crombrugghe B 2001 The chondrogenic transcription factor Sox 9 is a target of signaling by the parathyroid hormone-related peptide in the growth plate of endochondral bones. PNAS 98 160-165. (doi:10.1073/pnas.011393998)

Hwang WS 1978 Ultrastructure of human foetal and neonatal hyaline cartilage. Journal of Pathology 126 209-214. (doi:10.1002/path.1711260404)

Inada M, Wang Y, Byrne MH, Rahman MU, Miyaura C, Lopez-Otin C \& Krane SM 2004 Critical roles for collagenase-3 (Mmp13) in development of growth plate cartilage and in endochondral ossification. PNAS 101 17192-17197. (doi:10.1073/pnas.0407788101)

Jin W, Takagi T, Kanesashi SN, Kurahashi T, Nomura T, Harada J \& Ishii S 2006 Schnurri-2 controls BMP-dependent adipogenesis via interaction with Smad proteins. Developmental Cell 10 461-471. (doi:10.1016/j.devcel. 2006.02.016)

Joeng KS \& Long F 2009 The Gli2 transcriptional activator is a crucial effector for Ihh signaling in osteoblast development and cartilage vascularization. Development 136 4177-4185. (doi:10.1242/dev.041624)

Johansson N, Saarialho-Kere U, Airola K, Herva R, Nissinen L, Westermarck J, Vuorio E, Heino J \& Kahari VM 1997 Collagenase-3 (MMP-13) is expressed by hypertrophic chondrocytes, periosteal cells, and osteoblasts during human fetal bone development. Developmental Dynamics 208 387-397. (doi:10.1002/(SICI)1097-0177(199703)208:3<387::AIDAJA9 $>3.0 . \mathrm{CO} ; 2-\mathrm{E})$

Jones DC, Schweitzer MN, Wein M, Sigrist K, Takagi T, Ishii S \& Glimcher LH 2010 Uncoupling of growth plate maturation and bone formation in mice lacking both Schnurri-2 and Schnurri-3. PNAS 107 8254-8258. (doi:10.1073/pnas.1003727107)

Kaneshige M, Suzuki H, Kaneshige K, Cheng J, Wimbrow H, Barlow C, Willingham MC \& Cheng S 2001 A targeted dominant negative mutation of the thyroid hormone alpha 1 receptor causes increased mortality, infertility, and dwarfism in mice. PNAS 98 15095-15100. (doi:10.1073/ pnas.261565798)

Kawasaki Y, Kugimiya F, Chikuda H, Kamekura S, Ikeda T, Kawamura N, Saito T, Shinoda Y, Higashikawa A, Yano F et al. 2008 Phosphorylation of GSK-3beta by cGMP-dependent protein kinase II promotes hypertrophic differentiation of murine chondrocytes. Journal of Clinical Investigation 118 2506-2515. (doi:10.1172/JCI35243E1)

Kerr JF, Wyllie AH \& Currie AR 1972 Apoptosis: a basic biological phenomenon with wide-ranging implications in tissue kinetics. British Journal of Cancer 26 239-257. (doi:10.1038/bjc.1972.33)

Kirsch T 2006 Determinants of pathological mineralization. Current Opinion in Rheumatology 18 174-180. (doi:10.1097/01.bor.0000209431.59226.46)

Kirsch T, Nah HD, Shapiro IM \& Pacifici M 1997 Regulated production of mineralization-competent matrix vesicles in hypertrophic chondrocytes. Journal of Cell Biology 137 1149-1160. (doi:10.1083/jcb.137.5.1149)

Kirsch T, Harrison G, Golub EE \& Nah HD 2000 The roles of annexins and types II and X collagen in matrix vesicle-mediated mineralization of growth plate cartilage. Journal of Biological Chemistry 275 35577-35583. (doi:10. 1074/jbc.M005648200)

Kishimoto K, Kitazawa R, Kurosaka M, Maeda S \& Kitazawa S 2006 Expression profile of genes related to osteoclastogenesis in mouse growth plate and articular cartilage. Histochemistry and Cell Biology 125 593-602. (doi:10.1007/s00418-005-0103-z)

Klatt AR, Becker AK, Neacsu CD, Paulsson M \& Wagener R 2011 The matrilins: modulators of extracellular matrix assembly. International Journal of Biochemistry \& Cell Biology 43 320-330. (doi:10.1016/j.biocel.2010.12.010)

Ko Y, Kobbe B, Nicolae C, Miosge N, Paulsson M, Wagener R \& Aszodi A 2004 Matrilin-3 is dispensable for mouse skeletal growth and development. Molecular and Cellular Biology 24 1691-1699. (doi:10.1128/MCB.24.4. 1691-1699.2004)

Koyama E, Leatherman JL, Noji S \& Pacifici M 1996 Early chick limb cartilaginous elements possess polarizing activity and express hedgehog-related morphogenetic factors. Developmental Dynamics 207 344-354. (doi:10.1002/(SICI)1097-0177(199611)207:3<344::AIDAJA11 > 3.0.CO;2-4)

Koyama E, Young B, Nagayama M, Shibukawa Y, Enomoto-Iwamoto M, Iwamoto M, Maeda Y, Lanske B, Song B, Serra R et al. 2007 Conditional Kif3a ablation causes abnormal hedgehog signaling topography, growth plate dysfunction, and excessive bone and cartilage formation during mouse skeletogenesis. Development 134 2159-2169. (doi:10.1242/dev.001586)

Krakow D \& Rimoin DL 2010 The skeletal dysplasias. Genetics in Medicine 12 327-341.

Krejci P, Krakow D, Mekikian PB \& Wilcox WR 2007 Fibroblast growth factors 1, 2, 17, and 19 are the predominant FGF ligands expressed in human fetal growth plate cartilage. Pediatric Research 61 267-272. (doi:10. 1203/pdr.0b013e318030d157)

Kronenberg HM 2006 PTHrP and skeletal development. Annals of the New York Academy of Sciences 1068 1-13. (doi:10.1196/annals.1346.002)

Lee ER, Lamplugh L, Shepard NL \& Mort JS 1995 The septoclast, a cathepsin B-rich cell involved in the resorption of growth plate cartilage. Journal of Histochemistry and Cytochemistry 43 525-536. (doi:10.1177/43.5.7730591)

Lee K, Lanske B, Karaplis AC, Deeds JD, Kohno H, Nissenson RA, Kronenberg HM \& Segre GV 1996 Parathyroid hormone-related peptide delays terminal differentiation of chondrocytes during endochondral bone development. Endocrinology 137 5109-5118. (doi:10.1210/en.137.11.5109)

Lefebvre V \& Smits P 2005 Transcriptional control of chondrocyte fate and differentiation. Birth Defects Research. Part C, Embryo Today: Reviews $\mathbf{7 5}$ 200-212. (doi:10.1002/bdrc.20048)

Little CB, Meeker CT, Hembry RM, Sims NA, Lawlor KE, Golub SB, Last K \& Fosang AJ 2005a Matrix metalloproteinases are not essential for aggrecan turnover during normal skeletal growth and development. Molecular and Cellular Biology 25 3388-3399. (doi:10.1128/MCB.25.8.3388-3399.2005)

Little CB, Mittaz L, Belluoccio D, Rogerson FM, Campbell IK, Meeker CT, Bateman JF, Pritchard MA \& Fosang AJ 2005b ADAMTS-1-knockout mice do not exhibit abnormalities in aggrecan turnover in vitro or in vivo. Arthritis and Rheumatism 52 1461-1472. (doi:10.1002/art.21022) 
Maeda Y, Nakamura E, Nguyen MT, Suva LJ, Swain FL, Razzaque MS, Mackem S \& Lanske B 2007 Indian hedgehog produced by postnatal chondrocytes is essential for maintaining a growth plate and trabecular bone. PNAS 104 6382-6387. (doi:10.1073/pnas.0608449104)

Mak KK, Chen MH, Day TF, Chuang PT \& Yang Y 2006 Wnt/beta-catenin signaling interacts differentially with Ihh signaling in controlling endochondral bone and synovial joint formation. Development 133 3695-3707. (doi:10.1242/dev.02546)

Mak KK, Kronenberg HM, Chuang PT, Mackem S \& Yang Y 2008 Indian hedgehog signals independently of PTHrP to promote chondrocyte hypertrophy. Development 135 1947-1956. (doi:10.1242/dev.018044)

Matsumoto K, Li Y, Jakuba C, Sugiyama Y, Sayo T, Okuno M, Dealy CN, Toole BP, Takeda J, Yamaguchi Y et al. 2009 Conditional inactivation of Has2 reveals a crucial role for hyaluronan in skeletal growth, patterning, chondrocyte maturation and joint formation in the developing limb. Development 136 2825-2835. (doi:10.1242/dev.038505)

Matsushita T, Wilcox WR, Chan YY, Kawanami A, Bukulmez H, Balmes G, Krejci P, Mekikian PB, Otani K, Yamaura I et al. 2009 FGFR3 promotes synchondrosis closure and fusion of ossification centers through the MAPK pathway. Human Molecular Genetics 18 227-240. (doi:10.1093/hmg/ ddn339)

Minina E, Wenzel HM, Kreschel C, Karp S, Gaffield W, McMahon AP \& Vortkamp A $2001 \mathrm{BMP}$ and Ihh/PTHrP signaling interact to coordinate chondrocyte proliferation and differentiation. Development 128 4523-4534.

Minina E, Kreschel C, Naski MC, Ornitz DM \& Vortkamp A 2002 Interaction of FGF Ihh/Pthlh, and BMP signaling integrates chondrocyte proliferation and hypertrophic differentiation. Developmental Cell 3 439-449. (doi:10.1016/S1534-5807(02)00261-7)

Morishima A, Grumbach MM, Simpson ER, Fisher C \& Qin K 1995 Aromatase deficiency in male and female siblings caused by a novel mutation and the physiological role of estrogens. Journal of Clinical Endocrinology and Metabolism 80 3689-3698. (doi:10.1210/jc.80.12.3689)

Napierala D, Sam K, Morello R, Zheng Q, Munivez E, Shivdasani RA \& Lee B 2008 Uncoupling of chondrocyte differentiation and perichondrial mineralization underlies the skeletal dysplasia in tricho-rhino-phalangeal syndrome. Human Molecular Genetics 17 2244-2254. (doi:10.1093/hmg/ ddn125)

Nilsson O, Marino R, De Luca F, Phillip M \& Baron J 2005 Endocrine regulation of the growth plate. Hormone Research 64 157-165. (doi:10. 1159/000088791)

Nishioka K, Itoh S, Suemoto H, Kanno S, Gai Z, Kawakatsu M, Tanishima H, Morimoto Y, Hatamura I, Yoshida M et al. 2008 Trps1 deficiency enlarges the proliferative zone of growth plate cartilage by upregulation of Pthrp. Bone 43 64-71. (doi:10.1016/j.bone.2008.03.009)

Ornitz DM 2005 FGF signaling in the developing endochondral skeleton. Cytokine E Growth Factor Reviews 16 205-213. (doi:10.1016/j.cytogfr.2005 $02.003)$

Pass C, MacRae VE, Ahmed SF \& Farquharson C 2009 Inflammatory cytokines and the GH/IGF-I axis: novel actions on bone growth. Cell Biochemistry and Function 27 119-127. (doi:10.1002/cbf.1551)

Pavasant P, Shizari T \& Underhill CB 1996 Hyaluronan contributes to the enlargement of hypertrophic lacunae in the growth plate. Journal of Cell Science 109 327-334.

Poole CA, Flint MH \& Beaumont BW 1985 Analysis of the morphology and function of primary cilia in connective tissues: a cellular cybernetic probe? Cell Motility 5 175-193. (doi:10.1002/cm.970050302)

Posey KL, Hankenson K, Veerisetty AC, Bornstein P, Lawler J \& Hecht JT 2008 Skeletal abnormalities in mice lacking extracellular matrix proteins, thrombospondin-1, thrombospondin-3, thrombospondin-5, and type IX collagen. American Journal of Pathology 172 1664-1674. (doi:10.2353/ajpath. 2008.071094)

Reponen P, Sahlberg C, Munaut C, Thesleff I \& Tryggvason K 1994 High expression of $92 \mathrm{kD}$ type IV collagenase (gelatinase B) in the osteoclast lineage during mouse development. Journal of Cell Biology 124 1091-1102. (doi:10.1083/jcb.124.6.1091)

Retting KN, Song B, Yoon BS \& Lyons KM 2009 BMP canonical Smad signaling through Smad1 and Smad5 is required for endochondral bone formation. Development 136 1093-1104. (doi:10.1242/dev.029926)
Roach HI \& Clarke NM 1999 "Cell paralysis" as an intermediate stage in the programmed cell death of epiphyseal chondrocytes during development. Journal of Bone and Mineral Research 14 1367-1378. (doi:10.1359/jbmr.1999. 14.8.1367)

Roach HI \& Clarke NM 2000 Physiological cell death of chondrocytes in vivo is not confined to apoptosis. New observations on the mammalian growth plate. Journal of Bone and Joint Surgery. British Volume 82 601-613. (doi:10. 1302/0301-620X.82B4.9846)

Roach HI, Aigner T \& Kouri JB 2004 Chondroptosis: a variant of apoptotic cell death in chondrocytes? Apoptosis 9 265-277. (doi:10.1023/B:APPT. 0000025803.17498.26)

Rodgers KD, San Antonio JD \& Jacenko O 2008 Heparan sulfate proteoglycans: a GAGgle of skeletal-hematopoietic regulators. Developmental Dynamics 237 2622-2642. (doi:10.1002/dvdy.21593)

Rogerson FM, Stanton H, East CJ, Golub SB, Tutolo L, Farmer PJ \& Fosang AJ 2008 Evidence of a novel aggrecan-degrading activity in cartilage: studies of mice deficient in both ADAMTS-4 and ADAMTS-5. Arthritis and Rheumatism 58 1664-1673. (doi:10.1002/art.23458)

Saftig P, Hunziker E, Wehmeyer O, Jones S, Boyde A, Rommerskirch W, Moritz JD, Schu P \& von Figura K 1998 Impaired osteoclastic bone resorption leads to osteopetrosis in cathepsin-K-deficient mice. PNAS 95 13453-13458. (doi:10.1073/pnas.95.23.13453)

Schenk RK, Spiro D \& Wiener J 1967 Cartilage resorption in the tibial epiphyseal plate of growing rats. Journal of Cell Biology 34 275-291. (doi:10.1083/jcb.34.1.275)

Schibler L, Gibbs L, Benoist-Lasselin C, Decraene C, Martinovic J, Loget P, Delezoide AL, Gonzales M, Munnich A, Jais JP et al. 2009 New insight on FGFR3-related chondrodysplasias molecular physiopathology revealed by human chondrocyte gene expression profiling. PLOS ONE 4 e7633. (doi:10.1371/journal.pone.0007633)

Settembre C, Arteaga-Solis E, McKee MD, de Pablo R, Al Awqati Q, Ballabio A \& Karsenty G 2008 Proteoglycan desulfation determines the efficiency of chondrocyte autophagy and the extent of FGF signaling during endochondral ossification. Genes and Development 22 2645-2650. (doi:10.1101/ gad.1711308)

Shao YY, Wang L \& Ballock RT 2006 Thyroid hormone and the growth plate. Reviews in Endocrine and Metabolic Disorders 7 265-271. (doi:10.1007/ s11154-006-9012-2)

Smith EP, Boyd J, Frank GR, Takahashi H, Cohen RM, Specker B, Williams TC, Lubahn DB \& Korach KS 1994 Estrogen resistance caused by a mutation in the estrogen-receptor gene in a man. New England Journal of Medicine 331 1056-1061. (doi:10.1056/ NEJM199410203311604)

Stanton H, Rogerson FM, East CJ, Golub SB, Lawlor KE, Meeker CT, Little CB, Last K, Farmer PJ, Campbell IK et al. 2005 ADAMTS5 is the major aggrecanase in mouse cartilage in vivo and in vitro. Nature 434 648-652. (doi:10.1038/nature03417)

Stevens DA, Hasserjian RP, Robson H, Siebler T, Shalet SM \& Williams GR 2000 Thyroid hormones regulate hypertrophic chondrocyte differentiation and expression of parathyroid hormone-related peptide and its receptor during endochondral bone formation. Journal of Bone and Mineral Research 15 2431-2442. (doi:10.1359/jbmr.2000.15.12.2431)

Stickens D, Behonick DJ, Ortega N, Heyer B, Hartenstein B, Yu Y, Fosang AJ, Schorpp-Kistner M, Angel P \& Werb Z 2004 Altered endochondral bone development in matrix metalloproteinase 13-deficient mice. Development 131 5883-5895. (doi:10.1242/dev.01461)

St-Jacques B, Hammerschmidt M \& McMahon AP 1999 Indian hedgehog signaling regulates proliferation and differentiation of chondrocytes and is essential for bone formation. Genes and Development 13 2072-2086. (doi:10. 1101/gad.13.16.2072)

Suemoto H, Muragaki Y, Nishioka K, Sato M, Ooshima A, Itoh S, Hatamura I, Ozaki M, Braun A, Gustafsson E et al. 2007 Trps1 regulates proliferation and apoptosis of chondrocytes through Stat3 signaling. Developmental Biology 312 572-581. (doi:10.1016/j.ydbio.2007.10.001)

Svensson L, Aszodi A, Heinegard D, Hunziker EB, Reinholt FP, Fässler R \& Oldberg A 2002 Cartilage oligomeric matrix protein-deficient mice have normal skeletal development. Molecular and Cellular Biology 22 4366-4371. (doi:10.1128/MCB.22.12.4366-4371.2002) 
Tamamura Y, Otani T, Kanatani N, Koyama E, Kitagaki J, Komori T, Yamada Y, Costantini F, Wakisaka S, Pacifici M et al. 2005 Developmental regulation of Wnt/beta-catenin signals is required for growth plate assembly, cartilage integrity, and endochondral ossification. Journal of Biological Chemistry 280 19185-19195. (doi:10.1074/jbc.M414275200)

Taniguchi N, Yoshida K, Ito T, Tsuda M, Mishima Y, Furumatsu T, Ronfani L, Abeyama K, Kawahara K, Komiya S et al. 2007 Stage-specific secretion of HMGB1 in cartilage regulates endochondral ossification. Molecular and Cellular Biology 27 5650-5663. (doi:10.1128/MCB.00130-07)

Tew SR, Murdoch AD, Rauchenberg RP \& Hardingham TE 2008 Cellular methods in cartilage research: primary human chondrocytes in culture and chondrogenesis in human bone marrow stem cells. Methods 45 2-9. (doi:10. 1016/j.ymeth.2008.01.006)

Tryfonidou MA, Hazewinkel HA, Riemers FM, Brinkhof B, Penning LC \& Karperien M 2010 Intraspecies disparity in growth rate is associated with differences in expression of local growth plate regulators. American Journal of Physiology. Endocrinology and Metabolism 299 E1044-E1052. (doi:10.1152/ ajpendo.00170.2010)

Usui M, Xing L, Drissi H, Zuscik M, O'Keefe R, Chen D \& Boyce BF 2008 Murine and chicken chondrocytes regulate osteoclastogenesis by producing RANKL in response to BMP2. Journal of Bone and Mineral Research 23 314-325. (doi:10.1359/jbmr.071025)

Vortkamp A, Lee K, Lanske B, Segre GV, Kronenberg HM \& Tabin CJ 1996 Regulation of rate of cartilage differentiation by Indian hedgehog and PTH-related protein. Science 273 613-622. (doi:10.1126/science.273. 5275.613)

Vu TH, Shipley JM, Bergers G, Berger JE, Helms JA, Hanahan D, Shapiro SD, Senior RM \& Werb Z 1998 MMP-9/gelatinase B is a key regulator of growth plate angiogenesis and apoptosis of hypertrophic chondrocytes. Cell 93 411-422. (doi:10.1016/S0092-8674(00)81169-1)

Wang L, Shao YY \& Ballock RT 2007 Thyroid hormone interacts with the Wnt/beta-catenin signaling pathway in the terminal differentiation of growth plate chondrocytes. Journal of Bone and Mineral Research 22 1988-1995. (doi:10.1359/jbmr.070806)

Wang L, Shao YY \& Ballock RT 2010 Thyroid hormone-mediated growth and differentiation of growth plate chondrocytes involves IGF-1 modulation of beta-catenin signaling. Journal of Bone and Mineral Research 25 1138-1146. (doi:10.1002/jbmr.5)

Weise M, De-Levi S, Barnes KM, Gafni RI, Abad V \& Baron J 2001 Effects of estrogen on growth plate senescence and epiphyseal fusion. PNAS $\mathbf{9 8}$ 6871-6876. (doi:10.1073/pnas.121180498)

Wilsman NJ, Farnum CE \& Reed-Aksamit DK 1980 Incidence and morphology of equine and murine chondrocytic cilia. Anatomical Record 197 355-361. (doi:10.1002/ar.1091970309)

Wilsman NJ, Farnum CE, Hilley HD \& Carlson CS 1981 Ultrastructural evidence of a functional heterogeneity among physeal chondrocytes in growing swine. American Journal of Veterinary Research 42 1547-1553.

Wilsman NJ, Farnum CE, Leiferman EM, Fry M \& Barreto C 1996 Differential growth by growth plates as a function of multiple parameters of chondrocytic kinetics. Journal of Orthopaedic Research 14 927-936. (doi:10. 1002/jor.1100140613)

Wuelling M \& Vortkamp A 2010 Transcriptional networks controlling chondrocyte proliferation and differentiation during endochondral ossification. Pediatric Nephrology 25 625-631. (doi:10.1007/s00467-009-1368-6)
Wuelling M, Kaiser FJ, Buelens LA, Braunholz D, Shivdasani RA, Depping R \& Vortkamp A 2009 Trps1, a regulator of chondrocyte proliferation and differentiation, interacts with the activator form of Gli3. Developmental Biology 328 40-53. (doi:10.1016/j.ydbio.2009.01.012)

Yadav MC, Simao AM, Narisawa S, Huesa C, McKee MD, Farquharson C \& Millan JL 2011 Loss of skeletal mineralization by the simultaneous ablation of PHOSPHO1 and alkaline phosphatase function: a unified model of the mechanisms of initiation of skeletal calcification. Journal of Bone and Mineral Research 26 286-297. (doi:10.1002/jbmr.195)

Yamada T, Kawano H, Koshizuka Y, Fukuda T, Yoshimura K, Kamekura S, Saito T, Ikeda T, Kawasaki Y \& Azuma Y 2006 Carminerin contributes to chondrocyte calcification during endochondral ossification. Nature Medicine 12 665-670. (doi:10.1038/nm1409)

Yamashita S, Andoh M, Ueno-Kudoh H, Sato T, Miyaki S \& Asahara H 2009 Sox9 directly promotes Bapx1 gene expression to repress Runx2 in chondrocytes. Experimental Cell Research 315 2231-2240. (doi:10.1016/j. yexcr.2009.03.008)

Yang Y, Topol L, Lee H \& Wu J 2003 Wnt5a and Wnt5b exhibit distinct activities in coordinating chondrocyte proliferation and differentiation. Development 130 1003-1015. (doi:10.1242/dev.00324)

Yates KE, Shortkroff S \& Reish RG 2005 Wnt influence on chondrocyte differentiation and cartilage function. DNA and Cell Biology 24 446-457. (doi:10.1089/dna.2005.24.446)

Yoon BS, Pogue R, Ovchinnikov DA, Yoshii I, Mishina Y, Behringer RR \& Lyons KM 2006 BMPs regulate multiple aspects of growth-plate chondrogenesis through opposing actions on FGF pathways. Development 133 4667-4678. (doi:10.1242/dev.02680)

Zaucke F \& Grässel S 2009 Genetic mouse models for the functional analysis of the perifibrillar components collagen IX, COMP and matrilin-3: implications for growth cartilage differentiation and endochondral ossification. Histology and Histopathology 24 1067-1079.

Zelzer E, Glotzer DJ, Hartmann C, Thomas D, Fukai N, Soker S \& Olsen BR 2001 Tissue specific regulation of VEGF expression during bone development requires Cbfa1/Runx2. Mechanism of Development 106 97-106. (doi:10.1016/S0925-4773(01)00428-2)

Zelzer E, Mamluk R, Ferrara N, Johnson RS, Schipani E \& Olsen BR 2004 VEGFA is necessary for chondrocyte survival during bone development. Development 131 2161-2171. (doi:10.1242/dev.01053)

Zhang M, Xie R, Hou W, Wang B, Shen R, Wang X, Wang Q, Zhu T, Jonason JH \& Chen D 2009 PTHrP prevents chondrocyte premature hypertrophy by inducing cyclin-D1-dependent Runx2 and Runx3 phosphorylation, ubiquitylation and proteasomal degradation. Journal of Cell Science 122 1382-1389. (doi:10.1242/jcs.040709)

Zhou Z, Xie J, Lee D, Liu Y, Jung J, Zhou L, Xiong S, Mei L \& Xiong WC 2010 Neogenin regulation of BMP-induced canonical Smad signaling and endochondral bone formation. Developmental Cell 19 90-102. (doi:10. 1016/j.devcel.2010.06.016)

Received in final form 31 May 2011

Accepted 3 June 2011

Made available online as an Accepted Preprint 3 June 2011 